\title{
Use of Carazolol at Pre-Synchronized Timed Artificial Insemination in Cows
}

\author{
Ş. M. PANCARCI ${ }^{1}$, Y. ÖZTÜRKLER ${ }^{2}$, Ö. GÜNGÖR ${ }^{1}$, C. KAÇAR ${ }^{1}$, S. YILDIZ $^{2}$, D. KAYA ${ }^{1}$ \\ ${ }^{1}$ Department of Obstetrics \& Gynecology and Reproduction, \\ ${ }^{2}$ Department of Artificial Insemination and Reproduction, \\ Faculty of Veterinary Medicine, University of Kafkas, Kars, Turkey \\ Received June 26, 2007 \\ Accepted December 19, 2007
}

\begin{abstract}
Pancarci, Ş.M., Y. Öztürkler, Ö. Güngör, C. Kaçar, S. Yildiz, D. Kaya: Use of Carazolol at Pre-Synchronized Timed Artificial Insemination in Cows. Acta Vet. Brno 2008, 77: 59-64.

Efficacy of the $\beta$-adrenergic receptor blocker (carazolol) at Timed Artificial Insemination (TAI) was investigated. Cows $(\mathrm{n}=73)$ were pre-synchronized with two $\mathrm{PGF}_{2 \alpha}$ injections given $14 \mathrm{~d}$ apart to initiate the Ovsynch protocol at early and middle luteal stages $14 \mathrm{~d}$ later, and received injections of GnRH and $\mathrm{PGF}_{2 \alpha}$ seven d apart followed by GnRH $48 \mathrm{~h}$ later, and TAI 16 - $18 \mathrm{~h}$ later. Corpus luteum (CL) was detected via rectal palpation at the beginning of the Ovsynch protocol. Carazolol (Treatment I; $n=41$ ) or physiologic saline (Treatment II; $n=32$ ) were administered via jugular vein five min before TAI. Uterine tone was determined prior to infusion and at TAI via rectal palpation. Pregnancies were diagnosed with transrectal ultrasonography $40 \pm 7 \mathrm{~d}$ after TAI. Uterine tone was $2.8(1.4-5.3)$ times higher $(P<0.01)$ in Treatment I than that in Treatment II at TAI. Increase in uterine tone was affected by treatment $\times \mathrm{CL} \times$ parity $(P<0.05)$, and $66.7 \%, 75 \%$, $52.6 \%, 100 \%$ and $16.7 \%, 33.3 \%, 25 \%, 28.6 \%$ in primiparous cows with CL and without CL, and in multiparous cows with CL and without CL in Treatments I and II, respectively. Pregnancy rates did not differ between treatments I (34.2\%) and II (40.6\%). In conclusion, no beneficial effect of carazolol administration prior to TAI was found except for the increased uterine tone.
\end{abstract}

Ovsynch, carazolol, uterine tone, pregnancy, cow

A timed artificial insemination program (TAI), designated as the Ovsynch protocol has increased efficiency of reproductive management in dairy cows because all cows are inseminated at the designated voluntary waiting period without the need for oestrous detection, and pregnancy rates (PR) are optimal (Burke et al. 1996; Pursley et al. 1997). The Ovsynch protocol involves injection of GnRH given $48 \mathrm{~h}$ after injection of $\mathrm{PGF}_{2 \alpha}$ to ovulate a newly recruited dominant follicle at 24 to $32 \mathrm{~h}$ that was previously induced with the injection of $\mathrm{GnRH}$ and $\mathrm{PGF}_{2 \alpha}$ given a $7 \mathrm{~d}$ interval (Pursley et al. 1995). Cows can be artificially inseminated $16 \mathrm{~h}$ after the second GnRH injection owing to tight synchronization of ovulation (Pursley et al. 1998).

The uterine tone at the time of artificial insemination (AI) is important for PR in cows because contractions of myometrium accelerate the spermatozoa transport to oviduct and facilitate fertilization (Hammerl and Rüsse 1990; Kundig et al. 1990). The deposited number of spermatozoa is lower at AI than that at natural breeding, and life of the frozen-thawed spermatozoa is shorter than that of natural ejaculate (Dalton et al. 2001). Thus, PR could be lower following AI in the case of lower uterine tone and short lifespan of spermatozoa. Adrenaline released from sympathetic nerve endings causes a sympathomymetic effect by stimulating beta 2-adrenoreceptors on myometrium leading to suppression of uterine contractions (Miller 1967). Since cows are exposed to stress due to noise, bad handling etc. at AI, there could be an increase in adrenaline secretion resulting in stimulation of beta 2 -adrenoreceptors at myometrium. This adrenaline stimulation blocks the effect of oxytocin so that the uterine tone decreases, leading to a slower sperm transport and aged spermatozoa at the fertilization site. Fertilization with aged and less potential spermatozoa results in

Address for correspondence:

Şukru Metin Pancarci

Department of Obstetrics \& Gynecology and Reproduction

Faculty of Veterinary Medicine, University of Kafkas, 36100, Kars

TURKEY
Phone: +90 47424268 00/1234
Fax: +90 474 2426853
E-mail: smpancarci@hotmail.com
http://www.vfu.cz/acta-vet/actavet.htm 
embryonic loss (Dalton et al. 2001). Carazolol, a $\beta$-adrenergic receptor blocker, has an antagonistic effect on catecholamines. Increase in the uterine tone and PR were reported following carazolol administration prior to AI in cattle (Haas 1986; Hammerl and Rüsse 1990; Kirşan et al. 1998; Krebs 1988; Panowsky 1985). There is no study with regard to the use of carazolol in the Ovsynch protocol. Therefore, the objective of this experiment was to investigate the efficacy of carazolol administration prior to TAI.

\section{Materials and Methods}

This experiment was conducted on 73 lactating dairy cows (Brown Swiss, Simmental and their crossbreds with local breeds) in tied stall barn with access to pasture in the Kars District, Turkey. All animals were pre-

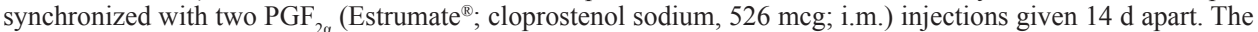
objective of the pre-synchronization protocol was to target a high percentage of cows to initiate the Ovsynch protocol at the most favourable stages ( 7 to 12) of the oestrous cycle (Moreira et al. 2001). All cows enrolled to the Ovsynch protocol, and were palpated per rectum for the presence of CL $14 \mathrm{~d}$ after the second $\mathrm{PGF}_{2 \alpha}$ injection of pre-synchronization, and received an injection of $\mathrm{GnRH}$ (Receptal ${ }^{\mathbb{R}} ; 0.021 \mathrm{mg}$ buserelin acetate, im). Seven $\mathrm{d}$ later $\mathrm{PGF}_{2 \alpha}$ was injected followed by the ovulatory injection of GnRH $48 \mathrm{~h}$ later, and TAI 16 to $18 \mathrm{~h}$ later. Animals were assigned randomly to receive either carazolol (Suacron ${ }^{\circledR}, 2.5 \mathrm{mg}$; treatment $\mathrm{I}, \mathrm{n}=41$ ) or physiologic saline (treatment II, $\mathrm{n}=32$ ) via jugular vein five min prior to TAI. Animals were palpated per rectum with ignorance of treatments to determine tonicity of the uterus immediately before injections and TAI. At each palpation, degrees of the uterine tones were evaluated using a 4-point scale (1 [no tone], 2 [slight tone], 3 [moderate tone] and 4 [extreme tone]). Afterwards, increases in uterine tones were calculated based on the differences of uterine tones at each palpation. For AI, a single insemination dose possessing $30-50 \times 10^{6} / \mathrm{ml}$ spermatozoa with at least $55 \%$ motile and $85 \%$ live spermatozoa was used. Body condition scores (BCS), using a 5-point scale (1 to 5) with intervals of 0.25 , were recorded during the Ovsynch protocol (Edmonson et al. 1989). Pregnancies were diagnosed with transrectal ultrasonography at $40 \pm 7 \mathrm{~d}$ after TAI.

PR following the first service and increased uterine tone were analyzed by the Logistic Regression-Stepwise Selection Procedure of SAS to determine independent variables among all variables and interactions. The mathematical model for PR included location, replicate (year), parity, treatment, day in milk (DIM) at the beginning of pre-synchronization, BCS, presence of CL, AI technician, sire, uterine tone at TAI, increase in uterine tone at TAI, and higher order interactions. The mathematical model for the increased uterine tone at TAI included location, replicate, parity, treatment, DIM, BCS, the presence of CL, AI technician, and higher order interactions. However, results for selected variables were reported as risk ratios to be more realistic as opposed to odds ratios following determination by stepwise procedure. The Proc Freq procedure of SAS was utilized to obtain frequency values and risk ratios. The Proc Univariate procedure of SAS was used to obtain median values of BCS and DIM.

For BCS, median value (2.75) was used as a cut point, and cows were classified as having poor (BCS $<=$ $2.75)$ or optimal $(\mathrm{BCS}>2.75)$ condition. For DIM, the median value (36) was used as a cut point, and cows were classified as early $(\mathrm{DIM}<=36)$ or late $(\mathrm{DIM}>36)$ postpartum.

\section{Results}

PR to the first service at $40 \pm 7 \mathrm{~d}$ following TAI did not differ between treatment I (14/41; $34.2 \%)$ and treatment II (13/32; 40.6\%; Fig. 1). Logistic regression-stepwise procedure indicated that interactions of presence of CL at the beginning of the Ovsynch protocol $\times \operatorname{BCS}(P<0.01)$, treatment $\times$ presence of $\mathrm{CL}$ at the beginning of the Ovsynch protocol $\times$ parity $(P<0.05)$ had an influence on PR. PR of cows having optimal BCS with $C L$, cows having poor BCS with $\mathrm{CL}$, cows having optimal BCS without $\mathrm{CL}$, cows having poor BCS without CL were 53.9\% (14/26), 33.3\% (9/27), 33.3\% (3/9) and 9.1\% (1/11), respectively. PR of primiparous cows with CL, primiparous cows without CL, multiparous cows with CL, multiparous cows without CL were $58.3 \%(7 / 12), 0 \%(0 / 4), 21.1 \%(4 / 19)$, $50 \%(3 / 6)$ and $66.7 \%(4 / 6), 0 \%(0 / 3), 50 \%(8 / 16)$ and $14.3 \%(1 / 7)$ in treatments I and II, respectively.

The distribution of cows with an increased uterine tone at TAI was significantly affected by treatment $(P<0.01)$ and interaction of treatment $\times$ presence of $C L$ at the beginning of the Ovsynch protocol $\times$ parity $(P<0.05)$. Increase in the uterine tone at TAI was $2.8(1.4$ - 5.3) times higher in cows injected with carazolol $(65.9 \%, 27 / 41)$ than those injected with physiologic saline prior to TAI $(25 \%, 8 / 32$; Fig. 1$)$. Rates of the increased uterine tone 


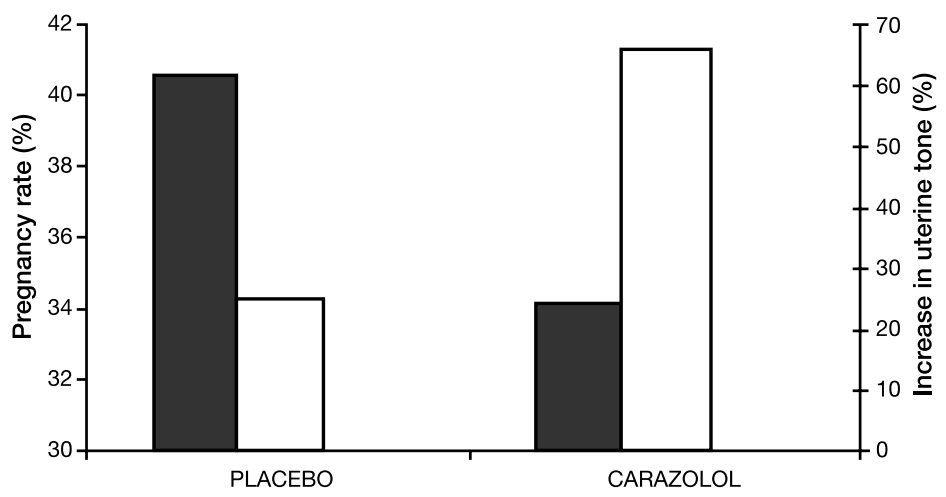

Fig. 1. Pregnancy rates (solid bars) $40 \pm 7 \mathrm{~d}$ following TAI and the rate of increase of the uterine tone (empty bars) at TAI in Treatment I (carazolol) and II (placebo). Pregnancy rates did not differ. The increase in the uterine tone at TAI was significantly affected by treatment $(P<0.01)$.

at TAI in primiparous cows with CL, primiparous cows without CL, multiparous cows with CL and multiparous cows without CL were $66.7 \%(8 / 12), 75 \%(3 / 4), 52.6 \%(10 / 19)$, $100 \%(6 / 6)$ and $16.7 \%(1 / 6), 33.3 \%(1 / 3), 25 \%(4 / 16), 28.6 \%(2 / 7)$ in Treatments I and II, respectively (Fig. 2). Absence of palpable CL at the beginning of the Ovsynch protocol was $27.4 \%(20 / 73)$ in this study.

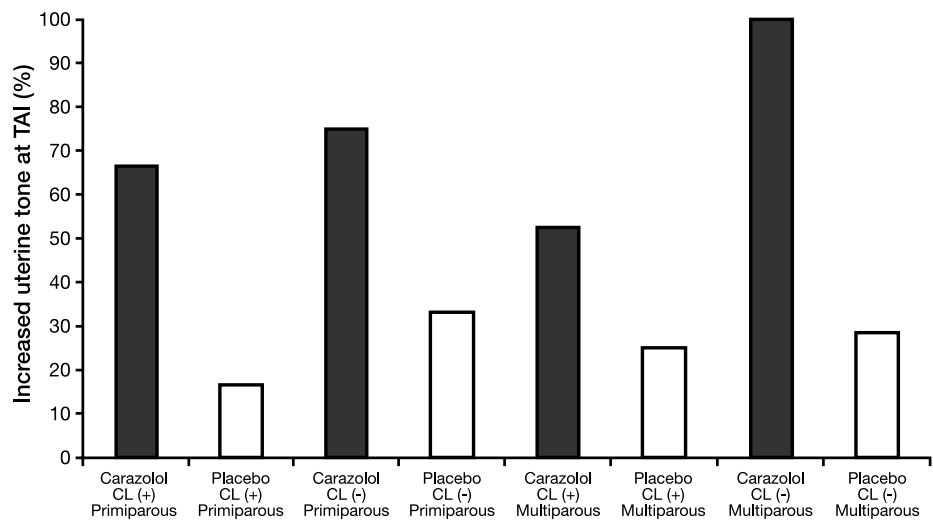

Fig. 2. Distribution of cows (\%) with an increased uterine tone at TAI in carazolol (treatment I) and placebo (treatment II) groups. Interaction of treatment $\times$ presence of CL at the beginning of the Ovsynch protocol $\times$ parity is significant $(P<0.05)$

\section{Discussion}

Significant interaction of presence of CL at the beginning of the Ovsynch protocol $\times$ BCS indicates the importance of BCS and pre-synchronization to achieve higher PR in TAI protocol. In this matter, the highest PR in cows having optimal BCS with CL and the lowest PR in cows having poor BCS without CL indicates the effect of BCS and presynchronization on the efficacy of TAI protocol in the current study.

No effect of the uterine tone at TAI on PR in buffalo following the Ovsynch was reported (De Araujo Berber et al. 2002). Similarly, no beneficial effect of the uterine tone on PR was found in the present study (Fig. 1). Higher uterine tone at TAI in anoestrous or non-synchronized cows (based on palpable CL) might be attributable to newly recruited 
ovulatory follicles escaped from luteinization by ovulatory injection of $\mathrm{GnRH}$ in the current study. In this regard, the higher uterine tone following carazolol administration in multiparous cows with no palpable CL at the beginning of the Ovsynch protocol could be due to higher rates of anoestrus or asynchrony. In contrast, cycling and synchronized cows might have a lower uterine tone due to luteinization of the ovulatory follicle leading to a decrease in confidence of AI technicians to the Ovsynch protocol (Fig. 2).

Numerically lower PR in carazolol treated group in this study is in disagreement with Kirşan et al. (1998) who reported higher PR following carazolol administration 3 - 5 min prior to AI following the detected oestrus in cattle; however, the time of AI relative to the onset of oestrus is not reported in that study. In this regard, PR to cows inseminated were lower for the Ovsynch program compared to conception rates of cows inseminated following the detected oestrus (Burke et al. 1996; Pursley et al. 1997; Stevenson et al. 1999). This lower PR to inseminated cows of the Ovsynch protocol compared to services made at detected oestrus could be due to insemination of all cows regardless of their cyclicity status and reproductive problems; whereas in the current study, tightly synchronized ovulation between 24 and $32 \mathrm{~h}$ following the Ovsynch protocol, and administration of carazolol immediately prior to TAI could probably result in numerically lower PR. A lower fertilization rate was reported following insemination of cows at the time of the onset of oestrus (Dalton et al. 2001). Probably, carazolol injection could increase the speed of spermatozoon transport to the fertilization site; thus, fertilization and embryo quality could be lower due to aged spermatozoa. Likewise, the administration of carazolol immediately prior to TAI could accelerate the transport of fertilized ovum in oviduct, and could cause disruption of synchrony between uterus and embryo because the effect of carazolol lasts up to 8 - $12 \mathrm{~h}$. Gajewski et al. (2006a) reported that carazolol has an inhibitory effect on progesterone secretion by cultured granulosa cells in cow. Numerically lower PR in carazolol treated group in our study could also be attributed to lower progesterone production by granulosa cells leading to impairment of the early embryonic development in oviduct.

The interaction effect of treatment $\times$ presence of CL at the beginning of the Ovsynch protocol $\times$ parity indicates that PR is lower in carazolol administered cows than that in control cows among multiparous cows with palpable CL; whereas, PR are similar among primiparous cows with palpable CL between treatments. Although there are no adequate cows in each category to formulate an assumption, these results imply that among carazolol administered animals the decrease in PR is more severe in multiparous than in primiparous cows with palpable CL. These lower PR in multiparous cows with palpable CL treated with carazolol could be explained by more reproductive disorders in multiparous cows compared to primiparous cows.

Similarly to non-significant PR in carazolol treated group in the current study, no significant effect of carazolol administration $30 \mathrm{~min}$ prior to AI following a detected oestrus on ovulation and PR was reported other than a numerically lower rate of delayed ovulation (Bostedt et al. 1995). No effect of carazolol treatment was reported with regard to the number of follicles and CL, embryo quality and effectiveness of AI during superovulation protocol in heifers (Gajewski et al. 2006b). In a study investigating the efficacy of a blockade of the stress-induced adrenergic action around AI by carazolol administration $54 \mathrm{~h}$ after the second $\mathrm{PGF}_{2 \alpha}$ injection given $11 \mathrm{~d}$ apart, it was found that the use of carazolol around the time of AI should be considered because carazolol administration following $\mathrm{PGF}_{2 \alpha}$ induced oestrus postponed the onset of oestrous expression despite no significant effect on gonadal steroids and LH release in cows (Perez et al. 2005). Thus, numerically lower PR in carazolol treated group in the current study could not be attributed to the effect of carazolol on LH release.

The anoestrous rate based on the presence of palpable CL at the beginning of the Ovsynch 
protocol was $27.4 \%$, and it was acceptable in our region. It was reported that the sensitivity, specificity and positive predictive value of palpation per rectum for identifying mid-cyclic CL were $85 \%, 95.7 \%$ and $89.5 \%$; respectively, with respect to plasma progesterone $\left(\mathrm{P}_{4}\right)$ concentrations (Ribadu et al. 1994). Similarly, detection of CL by palpation per rectum was verified by high concentrations of $\mathrm{P}_{4}$ only in $82 \%$ of the cases (Ott et al. 1986). Moreover, the absence of CL could reflect the failure of pre-synchronization because a high percentage of cows should have been on $\mathrm{d} 7$ to 12 of the oestrous cycle at the beginning of the Ovsynch protocol (Moreira et al. 2001).

In conclusion, no beneficial effects of the use of carazolol prior to TAI were found except for the increase in the uterine tone. Based on our results, we are unable to explain how other researchers achieved the increase in the conception rate following carazolol administration. Therefore, this experiment warrants further research to compare the effect of carazolol administration following natural and synchronized oestruses on the time of ovulation and fertility.

\section{Využití carazololu při synchronizaci ovulace k časované umělé inseminaci krav}

Byl zkoumán účinek $\beta$-adrenergního blokátoru (carazolol) při synchronizaci ovulace k časované umělé inseminaci krav (TAI). Sedmdesát tři krav bylo ošetřeno dvěma injekcemi PGF $_{2 \alpha}$ s odstupem 14 dní (zahájení Ovsynch metody v počáteční a stř̌ední luteální fázi o 14 dní později). Dále byly kravám aplikovány $\mathrm{GnRH}_{\text {a }} \mathrm{PGF}_{2 \alpha}$ s odstupem 7 dní a poté $\mathrm{GnRH}$ po $48 \mathrm{~h}$ a TAI byla provedena za 16 - 18 hod. Na počátku Ovsynch metody bylo rektálně detekováno corpus luteum (CL). Do v. jugularis byl 5 min před TAI aplikován carazolol (ošetření I; $n=41$ ) nebo fyziologický roztok (ošetření II; $n=32$ ). Před infuzí byl rektální palpací zkontrolován tonus dělohy. Březost byla diagnostikována transrektálním sonografickým vyšetřením $40 \pm 7$ dní po TAI. Tonus dělohy byl při TAI $2,8(1,4-5,3)$ krát větší $(P<0,01)$ v rámci ošetření I ve srovnání $\mathrm{s}$ ošetřením II. Zvýšení tonu dělohy bylo ovlivněno ošetřením, CL a paritou $(P<0,05)$, a $66,7 \%$, $75 \%, 52,6 \%, 100 \%$ a $16,7 \%, 33,3 \%, 25 \%, 28,6 \%$ u jalovic s CL a bez CL a u dojnic s CL a bez CL při ošetření I, respektive II. Počty březích krav se mezi ošetřeními I (34,2\%) a II (40,6\%) nelišily. Ze studie vyplývá, že aplikace carazololu před časovanou umělé inseminaci krav nemá pozitivní efekt, ale pouze zvyšuje tonus dělohy.

\section{Acknowledment}

Suacron ${ }^{\circledR}$ was generously donated by Bayer Animal Health, Istanbul, Turkey in this study.

\section{References}

BOSTEDT H, SELLINGER M, SCHULER G, FAILING K 1995: Ovulations- und Graviditätsresultat nach Anwendung eines GnRH-oder $\beta$-Blocker-Präparates prae inseminationem beim Milchrind. Tierarztl Umsch 50: $311-316$

BURKE JM, DE LA SOTA RL, RISCO CA, STAPLES CR, SCHMITT EJP, THATCHER WW 1996: Evaluation of timed insemination using a gonadotropin-releasing hormone agonist in lactating dairy cows. J Dairy Sci 79: $1385-1393$

DALTON JC, NADIR S, BAME JH, NOFTSINGER M, NEBEL RL, SAACKE RG 2001: Effect of time of insemination on number of accessory sperm, fertilization rate, and embryo quality in nonlactating dairy cattle. J Dairy Sci 84: 2413-2418

DE ARAUJO BERBER RC, MADUREIRA EH, BARUSELLI PS 2002: Comparison of two Ovsynch protocols (GnRH versus LH) for fixed timed insemination in buffalo (Bubalus bubalis). Theriogenology 57:1421-1430

EDMONSON AJ, LEAN IJ, WEAVER LD, FARVER T, WEBSTER G 1989: A body condition scoring chart for Holstein Dairy Cows. J Dairy Sci 72: 68-78

GAJEWSKİ Z, FAUNDEZ R, THUN R, PAWLINSKİ B 2006a: Adrenergic stimulation and blocking of hormonal secretion activity of cultured cow granulosa cells. J Physiol Pharmacol 57: 125-137

GAJEWSKİ Z, THUN R, FAUNDEZ R, PAWLINSKİ B 2006b: The influence of $\alpha$-adrenergic receptors stimulator and blockers and $\beta$-blocker on the ovary and endocrinological activity in heifers during superovulation. J Physiol Pharmacol 57: 173-188

HAAS BF 1986: Einfluss von $\beta$-Blockern (Beta-Blockern) und Opiatantagonisten auf die Trächtigkeitsrate bei der künstlichen Besamung des Rindes. Diss Med Vet München, 34 p. 
HAMMERL J, RÜSSEM 1990: Eine neue Methode der Diagnostik von Sterilitatsfallen in Rinderproblembetrieben. Tierarztl Umsch 45: 634-638

KIRŞAN İ, ALKAN S, BARAN A, ÖZTÜRKLER Y, ŞENÜNVER A, İLERI İK 1998: Einfluss des Beta 2blockers Carazolol auf die Trächtigkeitsrate und Uterus-tonus bei der künstlichen Besamung des Rindes. Istanbul Univ Vet Fac Derg 24: 89-95

KREBS J 1988: Der Einfluss der Dosis des Blockers Carazolol auf die Trächtigkeitsrate des Rindes im Rahmen der künstlichen Besamung (Feldversuch). Diss Med Vet München.

KUNDIG H, THUN R, ZEROBIN K, BACHMANN B 1990: Die Uterusmotorik des Rindes wärend Spätgravidität, Geburt und Puerperium. I. Die Spontanmotorik. Schweiz Arch Tierheilkd 132: 77-84

MILLER J W 1967: Adrenergic receptors in the myometrium. Ann NY Acad Sci 139:788-798

MOREIRA F, ORLANDI C, RISCO CA, MATTOS R, LOPES F, THATCHER WW 2001: Effects of presynchronization and bovine somatotropin on pregnancy rates to a timed artificial insemination protocol in lactating dairy cows. J Dairy Sci 84: 1646-1659

OTT RS, BRETZLAFF KN, HIXON JE 1986: Comparison of palpable corpora lutea with serum progesterone concentrations in cows. J Am Vet Med Assoc 188: 1417-1419

PANOWSKY G 1985: Einfluss von $\beta$-Blockern auf das Befruchtungsergebnis bei der künstlichen Besamung des Rindes. Diss Med Vet München, $73 \mathrm{p}$.

PEREZ CC, ESPAÑA F, SANTIAGO-MORENO J, ZIECIK AJ 2005: Influence of carazolol on progesterone, oestradiol and LH plasma concentrations and oestrous behaviour during the peri-ovulatory period in cows. Reprod Domest Anim 40: 362 (abstract P76)

PURSLEY JR, MEE MO, WILTBANK MC 1995: Synchronization of ovulation in dairy cows using PGF $_{2 \alpha}$ and GnRH. Theriogenology 44: 915-923

PURSLEY JR, WILTBANK MC, STEVENSON JS, OTTOBRE JS, GARVERICK HA, ANDERSON LL 1997: Pregnancy rates per artificial insemination for cows and heifers inseminated at a synchronized ovulation or synchronized estrus. J Dairy Sci 80: 295-300

PURSLEY JR, SILCOX RW, WILTBANK MC 1998: Effect of time of artificial insemination on pregnancy rates, calving rates, pregnancy loss, and gender ratio after synchronization of ovulation in lactating dairy cows. J Dairy Sci 81: 2139-2144

RIBADU AY, WARD WR, DOBSON H 1994: Comparative evaluation of ovarian structures in cattle by palpation per rectum, ultrasonography and plasma progesterone concentration. Vet Rec 135: 452-457

STEVENSON JS, KOBAYASHI Y, THOMPSON KE 1999: Reproductive performance of dairy cows in various programmed breeding systems including Ovsynch and combinations of gonadotropin-releasing hormone and prostaglandin $\mathrm{F}_{2 \alpha}$. J Dairy Sci 82: 506-515 